\title{
Arguing the American Dream à la Canada: Former Soviet Citizens' Justification for their Choice of Host Country
}

\author{
ROBERT F. BARSKY
}

Institurt National de to Recherche Scientfique Montred European Centre for the Study of Aygumentation Brusseds

This paper utilizes data accumulated from interviews with persons who claimed refugee status in Canada from the former Soviet Union, in order to assess the motivations claimants have for choosing particular host countries and the argumentative tactics employed to articulate the decision. The author argues that refugee claimants face innumerable obstacles once they have made the decision to leave the country of origin, not the least of which being the question of why they chose one country, in this case Canada, over another, and that their justification is often articulated through reference to. the American Dream. This Dream can function as a point of rapprochement between the claimant and the adjudicators because both parties are presumably in agreement concerning the basic.tenets of the claim, as well as a kind of tacit agreement concerning the character of America that the claimant asks the country to uphold. Assessing the character of the Dream, as described by claimants, also permits assessment to be made of the perception that potential claimants have of America, based upon the information available to them in the country of origin.

'I'm going to foreign parts, brother.'

'Foreign parts?'

'To America.'

'America?'

Svidrigaylov took out a revolver and cocked th.

Achilles raised his eyebrow.

'Vot now, this is not the place for jokes!'

'Why shouldn't it be the place?'

'Becouse it in't.'

'Well, brother, it doesn't matter. It's a good place... If you are asked, say I said I wis off to America." He lifted the revolver to his right tempte.

Fyodor Dostoyevsky, Crime and Provishment 
Introduction: Whose Dream?

The American Dream is a well-known vision amongst persons in the First World, one which is generally described in terms of possessions (house, car, boat, money), lifestyle (leisure time, nuclear family, employment), political vision (freedom, liberty, democracy) and possible worlds (immigration, integration, mobility). These visions change across time, reflecting general economic circumstances, levels of employment and perspectives of the viewer, but whether this viewer is gazing longingly at American society from the outside, or staring desperately at their own version of American society from the inside, there are a number of constant elements, recurring predicates employed in people's descriptions of the American Dream which generally cluster around categories of liberty and acquisition. However, for the seven male and seven female Convention refugee claimants between the ages of 22 and 42 from the former Soviet Union (seven Russians, four Ukrainians, two Kazaks and one Estonian) who claimed status in Québec in 1992 (1.2 per cent of the 1,168 who claimed that year) and who were interviewed for a research project undertaken at Québec's Institut National de la Recherche Scientifique, this Dream represents the precious point of contact between themselves and the country into which they hope to be accepted. For them, the American Dream may well be an aspiration, a propagandistic construct, a domestic lie, and a self-serving paradox; but it can also be an argumentative strategy constructed to help justify the choice of America (and, more particularly, Canada) in light of a growing corpus of legislation that impedes refugees' freedom of flight and limits the choice of potential host countries.'

After bribing their way out of and flecing from a country of origin, these refugee claimants argued their way in to a host country, in this case Canada. Is 'arguing one's way in' an overly sardonic description of a long, carefully administered adjudication process? Perhaps; the Canadian Immigration and Refugee Board (like other decision-making bodies of its kind throughout the world) does have at its disposal a number of resources to verify information provided by the claimant, including documentation centres, researchers, media reports, and the data amassed in the course of other hearings involving claimants from the same country of origin. But can these sources confirm that a particular individual has been subjected to the kinds of torture that would suggest a well-founded fear of persecution, and therefore a ćredible claim? Can they evahuate whether the claimant has indeed both practised a particular religion, and then been persecuted for this practice? Can they offer evidence that a claimant who has confounded relevant details of the case has done so because of the fraudulent nature of the claim, rather than because she or he has been tortured and, as a result, suffers from trauma-instilled disorientation? Since these questions cannot be answered with a high degree of certainty, might it not be reasonable that the adjudicators evaluate the method of expression employed by the claimant when considering the case? But even this could lead to dubious treatment of claims because the smooth and meticulous delivery of 
testimony could either be a sign that the person has not been persecuted but instead has thoroughly memorized details appropriate to a fictitious but wellfounded claim, or it could be proof that the claimant was indeed persecuted and that this recollection is evidence that the experience was formative. In fact, examined from a certain perspective, these hearings could be described as rites of passage rather than fact-finding missions, for it would be easier to determine the kinds of concerns and values that underwrite a host country from the kinds of questions posed during a hearing, the manner by which they are posed, and the kinds of claims admitted, than to determine whether the claimants have or have not actually been subjected to the kinds of persecution deemed admissible for a well-founded fear (Barsky 1994a). This is not as perverse an argument as it sounds; when transcriptions of cases are read with a view to discerning questions aimed at, say, determining the qualities of the claimant as a potential Canadian citizen (education, employment record, criminal behaviour, domestic life) rather than evahuating whether the person has a well-founded fear, then claimants' replies begin to sound like whatever the claimant thinks that the Board wants to hear. Therefore, it is my contention that to analyse the hearing as a rite of passage with regards to particular argumentative strategies may help further explain the preconceptions and perceptions that the claimant has of the host country, as well as the host country's views on appropriate criteria for admitting claimants, with the latter being, among other things, akin to a test of the claimant's ability to act appropriately in a formalized legal setting as much as an evaluation of the claim.

\section{The American Dream as 'Rite of Passage' Through the Third Country Clanse}

The impediments to this rite of passage, which are similar in most countries of the First World, are monumental and well documented. Even a small survey thereof would have to take into account a broad range of impeding phenomena, including international power relations (Chomsky 1972, 1978, 1992), economic factors (Chambers 1986:245-263), transportation routes (Bollag and Crisp 1987:17-18; Crisp 1987:15-17; Den Hond 1988:49-56; Grahl-Madsen 1987:213-235; Jaeger 1988:23-48), cultural differences (Geertz 1983), racism (Essed 1991; Van Dijk 1987) anti-semitism (Abella and Troper 1982), xenophobia (Ebel and Fiala 1983), bureaucratic rituals (Barsky 1995; Hathaway 1993), language barriers (Barsky 1993:131-156; Bickley 1982:99125; Gudykunst and Young 1984; Kalin 1986:230-241; Koole and Ten Thije 1994) and policies specific to Canada (Adelman 1991; Gilad 1990; Hathaway 1990:129-183; 1991a; 1991 b:113-31; Helly 1992). The barrier in question for the present discussion is the 'choice of country'. That is, given the options available to a claimant who has left the country of origin, and given trajectories that sometimes bring claimants through several seemingly 'safe countries', why did they nonetheless persist on to North America (more than one-half of the claimants interviewed had stopovers in Europe) and, eventually, Canada (onethird of the claimants spent from two days to six months in the United States)? 
The choice of country 'can be a 'barrier' to entry, because in certain circumstances the fact that a claimant did not claim status in the first country through which she or he passed makes it look as though she or he was not fleeing danger, but was rather shopping around for a new and easily accessible place to ask for status, an action that is now specifically prohibited in certain European countries under recently passed 'third country' legislation. As yet, Canada has not implemented a list of countries to which people can be returned to make their claims, nor has it signed any bi- or multi-lateral agreements; but the spirit of such a clause exists in the suspicion that long trajectories elicit. Furthermore, the framework for an eventual 'third country clause' has been set in several bills, most recently in 1993 with the passage of Bill C-86, which states that:

46.01 (1) A person who claims to be a Convention refugee is not eligible to have the claim determined by the Refugee Division if the person

(a)...

(b) came to Canada, directly or indirectly, from a country, other than a country of the person's nationality or, where the person has no country of nationality, the country of the person's habitual residence, that is a prescribed country under paragraph $114(1)(s)$.

Previously, there had been vague reference to the need for a Committee which would be responsible to advise the Minister with respect to prescribing countries which would be 'safe' (the Immigration Act, 1976-1977, c. 52, s. 114(5)); in C-86 the legislators have been more forthright, 'prescribing, for the purpose of sharing responsibility for the examination of persons who claim to be Convention refugees, countries that comply with Article 33 ("Prohibition of expulsion or return-refoulement") of the Convention' (R. S. c. 28, 4th supp., ss. 29(3),(4)). This could be interpreted to mean that if you leave your country of origin, whatever the circumstances, and you stop over in one or several 'safe' countries while en route, then you will be returned to one of those countries through which you passed. Many asylum seekers are in fact physically restricted in their choice of host country by visa requirements which are very effective impediments, particularly for countries (like Canada) that are far afield from many claim countries and therefore less likely to be on direct flight routes. Although in apparent violation of the spirit (if not the letter) of the Universal Declaration of Human Rights, the Convention Relating to the Status of Refugees (notably Article 1 and Article 33, since any notion of 'safe third country' could only be tested through full hearing), the Protocol to the Convention, and the Declaration on Territorial Asyhum, this clause (and others like it) has been invoked and utilized with a high degree of success to limit the flow of refugees, in particular those moving from the Third to the First World. If the tenets of such a clause were to be invoked, particularly in a systematic fashion in important 'turnstile' airports such as Amsterdam-Schiphol, LondonHeathrow, Geneva-Cointrin and Zürich-Kloten, then the possibility that persons could flee from persecution with the hope of asylum in a safe country 
that is far from the country of origin would be significantly diminished, particularly for the poor and the disenfranchised. Grahl-Madsen writes in this regard:

It seems that the trick is that in order to change plans in a transit airport, say, Franlfurt am Main, the traveller needs a transit visa (provided that he does not belong to one of the nationalities exempt from the visa requirement). And such a visa is regularly refused to potential asyhum-seckers. When the same procedure is followed in other major aiports such as Amsterdam-Schiphol, LondonHeathrow, Geneva-Cointrin and Zürich-Kloten, there are very few avenues left, and Western Europe is for all practical purposes turned into 'Fortress Europe,' closed to people of the Third World (1987:233).

Persecuted persons rarely have the material means, the documentation or the connections needed to make direct flights abroad; but given the success of such legislation in Europe as a means of limiting flows to (and from) certain countries, the wider utilization of such measures may not be far off. Not all claimants meed to choose one particular country over another; but the possibility does exist, and the idea that they should simply claim as soon as they can sounds like a convenient excuse for limiting migration of undesirables to a sphere far from our own.

\section{Constructing an American Dream as Argumentative Strategy}

Refugee claimants, who already face scrutiny of virtually every decision they have made leading to and subsequent to their persecution, must justify their presence in a potential safe haven either for judicial reasons (in Europe) or in order to establish 'credibility' (in Canada). How do claimants explain their sometimes long trajectories? Why do they not simply make a claim at the first opportune moment, regardless of the host country? Do they specifically target Canada or Québec, and if so, why? These are questions that are sometimes implicitly or explicitly answered during the hearings with regards to some version of the 'American Dream', and they represent one area of discussion in an unpublished report describing choices made by claimants who fled Israel, Pakistan, Peru and the former Soviet Union to claim status in Canada in 1992 (Barsky 1994b). Sometimes the answers to these questions were in accord with anticipated results; many claimants felt that they would not have been safe in countries (typically perceived as being 'safe') for reasons related to their profile or country of origin. It is true that they may in certain cases have been wrong; but since the claimant is the one who has suffered, and since it would be irrational for him or her to prolong this suffering through inappropriate choice of host country, should this be grounds for forbidding free choice of host country? It may well be argued that the choice not to make a claim in a transit country could be grounds to consider that the claim is indeed genuine, rather than an indication to the contrary, because by acting on the basis of selfpreservation the claimant has behaved according to a criterion that we as 
Canadians would apply as regards our own decisions. Sometimes, by contrast, interviewees confirmed what many anti-refugee groups claim; many interviewees came to Canada because they did not think they would be accepted in other countries (in this survey, two of the fourteen interviewees cited this as the primary reason for their choice of Canada). That this should be proof of their illegitimacy is perverse; why should persons, simply on account of their having been persecuted, be expected to act in a manner that runs counter to their own interests? There were other reasons, sometimes mentioned in combination, for selecting Canada, notably: the presence of friends or acquaintances (six) or family (one); some elements of chance (five; this was particularly true for the sailors in the group, of which there were two); perceived or known characteristics of Canadian (or Québecois) society (two: one on the basis of its 'nature' and geography, and the other for unspecified forces that made her want it 'from her soul'); the personal characteristics of the claimant (two: one was pregnant and did not wish to pay for a hospital in the United States; the other, accompanying her husband who had received a visa to study a new surgical technique in Canada, suffered frequent beatings at his hands and therefore requested status after having left him in Montréal); the perception that there are strong resemblances between Canada and the country of origin (two); airport, visa and immigration restrictions (two, both resulting from rejection in the United States); and the site of Montreal (or other Canadian cities) in relation to international aviation routes and natural barriers (two, both relating to its proximity to the point of entry to America, i.e. New York). One of the claimants did not choose Canada but came on account of her husband, and one did not want to come to Canada but was unable to obtain status in her first two choices (United States and Israel).

There was another, unanticipated motivation for choosing Canada as host country: the claimant's desire to live up to or fulfil an American Dream (à la Canada). This is not necessarily a caprice, the realization of some Utopic fantasy; persons who have been persecuted in a country of origin may feel that they need a 'new beginning' far away from the familiar, or else they feel particularly well equipped to fulfil or live up to such a dream, imagining that America, the land of immigrants, is particularly well suited-given his/her particular profile, objectives and qualifications _and that 'America' would in fact be enriched by the claimant's anticipated prosperity.

\section{Versions of the Refugees' American Dream}

In order to describe the various versions of the Dream, the America described by the claimants interviewed for this project will be sketched out; and in order to evaluate how this Dream is employed as rational argumentative strategy during the interviews, the process of fashioning the Dream around perceptions that the claimants have of themselves will be described. It should be noted that through examination of documents submitted to the hearing, and through my participation, as 'expert witness', in hearings for interviewees, it became clear 
that the argumentative quality present in the interviews resembles, indeed approximates, the argumentative quality present in the documents submitted to the courts on behalf of these same claimants. This is the case both in terms of style and content, and the observations made on the basis of the interviews would therefore apply as well to actual hearings.

These are complex issues, particularly as regards the persons from the former Soviet Union, and the description that follows cannot always be described in terms of quantitative evidence, because the 'American Dream' is invoked for different reasons and with varying ends in the course of the interviews. Nonetheless, some general and provocative tendencies can be noted. The anticipated reply to questions concerning the American Dream was an assemblage of often contradictory reported speech, situated somewhere between Radio Free America and Pravda, Hollywood and anti-imperialist buzzwords, Stars on Ice and impoverished ghetto dwellers, Don Rickles and Ronald Reagan, streets paved with gold and streets paved with human debris, hammer and sickle and Star Wars. Most of this range was present, of course, but this was not the intriguing element of the discourse, and to concentrate thereupon for purposes of colourful description, or to get caught up therein to elucidate the effects of on-going propaganda, whether it be Soviet or American, would be to miss the larger point. This is that refugees are thrust into a situation in which pragmatism is not only a logical pathway, it is the only pathway offered. The discourse is, in other words, task oriented. It is an attempt to construct a productive other, and invoking the American Dream during this construction process offers a possible justification for the choice of one country over another, situating the choice of country into both ideological and spatial terms; and it establishes (or the claimant might think it establishes) ground upon which the two parties to the hearing can discuss the claim. If the American Dream figures in the argumentative equation employed to solve the riddle of Canadian Refugee Board methods of determination, however, it cannot be invoked arbitrarily or equated to its corollary choice- the United States. It must first be broken down, then idealized or rendered more appropriate to the victim in question, and it must be contextualized to the Canadian circumstance. In other words, claimants must assemble the predicates associated with the American Dream in different ways than if the claim had been made in the US, where the sense of the American Dream is more commonly invoked and, so to speak, taken for granted.

In general terms, the American Dream as described by Convention refugee claimants closely resembles the one that Americans, subject to a similar level of (integration) propaganda, would probably invoke: America is a land of 'equal opportunity', 'liberty', 'California golden girls', 'rags to riches', 'greenbacks' and so forth. Each of these descriptions, which by the way are remarkably similar all across the spectrum of the ex-Soviet Union, from Belarus to Siberia, from Estonia to Russia, is a possible predicate, or a possible subject. In other words, each of the predicates could become subjects that reveal other levels of this dream (Meyer 1992). For example, if we ask the claimant to elaborate on 
what he means by the predicate 'liberty' as regards the American Dream, thereby transforming it into a subject, then a new set of predicates is evoked, such as 'future', 'democracy', 'elections', 'freedom of speech', or else 'Marines', 'US army', 'judicial system' and so forth, ad infinitum. The term 'American Dream', if taken without its associative predicates or if left as construct is, upon invocation, an attempt to establish, or destroy, all of these connotations by condensing them-again, a tactic appropriate to the choice of America as United States. However if the person chose to claim in America as Canada then the construct must be broken down, usually in response to the Immigration and Refugee Board's nearly inevitable questions (implied or stated), 'Why not the USA as target host country?, 'Why not choose to claim, or to pursue the claim, in the USA?, 'Why did you continue on to Montreal (or Toronto, or Vancouver) after your stopover in $\mathrm{X}$ third country?' and so forth. To reply to these questions, the claimant must break the Dream down into predicates appropriate to the argumentative ends. Failure to do so could produce gaps in the testimony, just as inappropriate responses could lead to strange or contradictory utterances. Concrete evidence of the ways in which said gaps or contradictions affect the outcome of the hearings is not available from this particular sampling because the question 'Did you have an American Dream and did it affect your choice of Canada? is not specifically asked during actual hearings; however, from my own participation in the hearings, studies of claims, and interviews for this project, I can confirm that contradictions, gaps and muddled testimony are all cited as reasons for refusing claims.

To this end, persons from the ex-Soviet Union, almost irrespective of the area of origin, are remarkably capable and, until 1992 when levels of acceptance fell to around 59 per cent from 72.4 per cent in 1991, their success rate in the refugee determination gambit may in some ways have reflected their abilities. This is not to suggest that the politics of refugee determination are necessarily overdetermined by argumentative strategies, but rather that this argumentative component does count inasmuch as it serves as an example to demonstrate why, or in which ways, our adjudicating system favours groups that reinforce the image it has of itself. Evidence for this observation is a story for another day; but briefly, it can be demonstrated with regards to the level of rejection in the case of the Pakistanis interviewed for this same project. As a group, the Pakistanis claimed a much higher level of persecution than persons from the former Soviet Union (all of the non-Ahmadis had been imprisoned and tortured, and all of the Ahmadis faced similar treatment if caught practising their religion), and yet were only marginally more successful than the Soviets (74.2 per cent were accepted in 1992, a similar percentage as that of the Soviets in 1991). It is either coincidental that the persons interviewed for this group were far less convincing and articulate than those from the former Soviet Union, or it may be simple racism on the part of Board members (none of the claimants interviewed from the former Soviet Union are coloured); but it may also be that Russians offer compelling arguments because they are familiar 
with and convincing according to the Canadian vahue system in ways that the Pakistanis (for example) are not.

America and the American Dream' for persons claiming Convention refugee status could be described according to a Russian saying: kvartira, mashina, dacha, dengi-an apartment, a car, a dacha and money. That is the first level, the American Dream in a nutshell. Another aspect, perhaps less dream-like but nonetheless consistently mentioned, is the fact that America is also a place to which people can go; the American Dream, by definition, implies a certain openness both in terms of policies towards immigrants, and in terms of available physical space. In terms of the former, many claimants mentioned that in America you can come and settle with success, what most refugees understand by the term 'multiculturalism'. Mark said:

I knew that Canada is a democratic country, and Canada signed the Convention for refugees, and Canada is a free country. Free and democratic is the same. All nationalities are equal. All races are equal. You can feel in Canada as a free person. You will not have discrimination from your nationality or from your race. A good country. I had an imagination of Canada that it liked peace and not war. That it does not have too much amy, as does Russia. A peaceful, democratic, country.

In terms of the latter, eleven of the fourteen persons mentioned geography as a motivation for choosing America, with nine of talking about the size of the country and (by extension) the space available for settlement. Oleg, for example, said:

When I was living in Hariem [where he stayed for several months] I got a map of North America and looked at Canada and thought, what a big country, and people only live in the Southern part! There must be a place for me. I'll live and be happy.

\section{The American Versas the Canatian Dream}

When pressed to provide layers of description with regards to this dream, claimants often distinguished between two different phenomena: first, the relationship between the America of their dreams versus the America described by Soviet propaganda; and second (also often related to propaganda), the differences between the United States and Canada. Amazingly enough, eleven of the fourteen persons interviewed referred to Soviet or American propaganda while responding to questions, but they were divided in opinions concerning its success. For example, the United States, though always described according to a series of hyperbolic adjectives, was either envisioned as a dream come true or a living hell. On the positive side, the United States is 'the number one country in the world, cconomically, politically, industrially' (Leonid); 'I really liked America. I liked John Kennedy because he was good looking. And he made extraordinary decisions. At that time we had $\mathrm{K}$ ruschev, and he was crazy. And 
now we have an alcoholic' (Elena); 'I like the American style there; cowboy hat, real men, little tie' (Oleg). But this American Dream, United States style, invariably has a massive downside, a sacrifice, which was its danger (half of the claimants mentioned crime as a reason for not choosing the United States and half-with some overlap-mentioned racial tensions or the presence of Blacks). This idealization versus anti-idealization is also reflected in their incisive discussions of propaganda, although five of the interviewees did affirm that Soviet propaganda concerning the United States had been successful (and was therefore a reason for them having chosen Canada). Alexander said:

When I was 7 or 8 I used to draw pictures of Montreal, and American flags, and American cities. I imagined it would be more beautiful. Nevertheless the USSR's propaganda worked. American soldiers are the enemy. There are problems with the states, with the police, the pollution.

Elena said:

Don't forget that because of the Cold War, the US was considered to be the enemy. Even though I tried to take positive impressions from the propaganda, it was implanted in us. We would see human faces and we would say that it looks nice, but then there was the pressure from the other side

and Ivana said:

I knew more. From movies. Military. Poverty, crime was described in every city. Danger, poverty, Blacks. I believed all of it; we all did.

Others said that the propaganda was for them a motivation to come to America: Lyubov said:

Only complete idiots thought that the US was a real enemy during the Cold War. It was nonsense. The only real sensation was that there was some pride in the Soviet Union because it was so powerful. This did exist. For Russie an enemy is somebody who really does attack. Otherwise it is just nonsense.

This sensitivity to the workings of propaganda also made some claimants wary of the 'American Dream', leading seven of the claimants to mention either sports or Hollywood while talking about propaganda. Finally, there were those who made an equivalence between American and Soviet propaganda, deciding that neither was true. The effect upon Nikolai was notable: 'In our films they add a bit, here it is the same thing. I don't believe what I see or read; only in what I touch with my hands. We were always deceived.' And Alexander said:

The more they stressed the negative aspects of the United States, the more people thought it was propaganda. In movie theatres they did not show positive movies about the US. They showed One Flew Over the Cuckoo's Nest, suggesting that all Americans who are active end up in a mental institution. Everybody knew that the same things happened in the Soviet Union. They would show films about the mafia, about Chicago, about assassinations of American presidents. When you nace tha 
to associate these things with the Americans. Who are cowboys? They are shepherds!

Whether the propaganda was believed or not, it was nonetheless necessary for claimants to give a reason for their having chosen Canada over the United States. Once the choice of 'America' is confirmed, the choice of Canada becomes a refinement, generally described in terms of the temperament of the claimant. This temperament provoked revulsion in the face of the high price that Americans pay for the fulfilment of their dream, and a propensity towards doubting an idealized vision of America as depicted in Hollywood films. Despite the fact that the interviewees invariably had a very strong grounding in geography, most of them describe the United States in terms of a small number of crime-ridden cities, notably New York, Chicago and Los Angeles. New York, the most frequently-mentioned, is riddled with murders, inter-racial tension, filth and noise. Chicago is often associated with gangsters, with descriptions and references that look back to the 'dirty '30s', and Los Angeles is geomorphologically dangerous and crime ridden. Because many claimants did spend some time in the United States, their visions of it were sometimes tested; and their negative impressions of the country often became a justification for coming to Canada. In one case, two Russian sailors left their ship in Baton Rouge, Louisiana, fully intending to stay in the United States. They were told to await their preliminary hearing in New York City. Since they could not afford an apartment, they stayed in Harlem; of the experience there, one of the sailors said:

When a person doesn't have too much information himself, then the situation can very much influence him. When I got to New York, I couldn't believe it; I never thought it was such a dark swamp of dirt, cockroaches, rats. I thought, AAAAAH!

This haunting vision of night-time in the US is best described according to another rule, this one taken from the descriptions in the interviews. At night, the US is 'darkened, dangerous and dirty'. The image of darkness with regards to the US is of tremendous importance; whatever the daylight dream might offer is offset by the dangers of Black people and of night-time crime. Nikolai was particularly concerned about this 'blackness':

I did not want to claim status in the United States. California is beautiful, but there are so many racial problems. I looked at those Black guys' eyes, and I fett as though it were a nightmare. What I mean is that I felt as though they hated me. When I drove through Oakland, on two occasions rocks were thrown at the car. I was in a car and they were menacing me, throwing rocks. Black people in Canada have a different mentality, a different look in their eyes. We look at each other in a very different way. Furthermore, I wanted to come only to Canada.

There is also a strange and unspecified danger that is often evoked with regards to the States. Elena said: 'The idea of the US was terrifying for us, in our understanding.' Part of this danger is a consequence of its great size; 
interestingly, this is taken to be a positive factor with regards to Canada (similar to home and lots of space for new immigrants), whereas with regards to the United States it was menacing. Tatiana said:

I did not want to ask for status in the US; it is big, intimidating and dangerous.

Canada was to me a nice, beautiful, calm country. Here they don't shoot people.

To complete the rather nightmarish vision of the US one must also add sound, a loud and menacing sound, as described by Tatiana: 'I knew it is a huge, noisy country.'

\section{The Canadian Dream}

The Canadian dream is best described as 'less', or 'fewer'. Canada is generally described as having less wealth, fewer people, fewer cars, fewer boats, fewer jobs. But it also has less drugs, fewer Blacks, fewer weapons, less shootings, less pollution, less noise, less discrimination, and, surprisingly, less emotion. Tatiana described Canada as 'calmer, quieter, more sane'. Leonid said 'I thought only White people lived here, because it is a Northern country'. Oleg called it 'a neutral country, in terms of the Cold War'. Finally, Valeri said:

Other than crime, I thought that Canada and the USA were almost identical. Their way of life was perhaps different in my mind. I saw Americans as more emotional; I thought that because of the films and because of things I had heard. I cannot really compare myself. I have this idea that in Canada everything is calmer, more balanced, more equal than in the US.

The emotion mentioned here relates to the 'calm', 'balance' and 'quiet' that is central to the Canadian Dream, and this vision is in accord with the ways in which these same claimants describe themselves. Canada in this regard is often compared to the country of origin; it has similarly frigid weather, good hockey players (Mark said: 'If the USSR is vodka, Gorbachev and perestroika, Canada is hockey games, maple trees and Brian Adams'), safe neighbourhoods, and a government which takes care of its people. Luda called Canada 'a very safe place, almost like Russia', and Oleg saw Canada as

closer to Russia. In terms of living conditions. We live in the same latitude. The conditions of life impose their effect upon people. I knew this in Estonia. I knew that Canada was a rich country, because it is a big country, rich in resources.

Canada was also described as a country that respects immigrants and refugees, offering them some hope that one day they will be treated like equals. This is interesting for two reasons. First, most claimants do not simply want to be accepted, they wish to be integrated, and they know that as foreigners they will have to suffer the difficulties and humiliations of outsiderness. Nikolai described American policy in this regard as follows:

No one helps you financially, no organizations or government bodies help you, and you are absolutely free! Please go and find some work! But the permission to 
work only lasts for one year. I could find decent work for $\$ 10.00$ per hour, but it was only for one year. After that nobody will prolong your stay. Your visa will expire after six months, and then you are a nothing. They will just say to you, "you are not a refugee'.

Leonid, providing an extremely important reason for refugees'. frequent mention of crime for having chosen Canada over the United States said:

The problems of crime are of great concern to refugees because they live in the streets often. They also live in poor regions.

The question of integration is also an often cited reason for continuing on from Europe. Four of the claimants, all women, stated that they would sooner have gone to Europe but that they would not have been admitted or, if admitted, would not be integrated. Svetlana summed up their views:

I knew that all the countries in Europe had rich culture, beautiful, developed. But they don't need immigrants.

The geographical component, mentioned earlier with regards to open and available space for refugees, played a critical role in claimants' descriptions of the Canadian Dream. Eleven claimants mentioned geography as motivation for choosing Canada, with seven talking about the beauty of Canada's nature and, surprisingly, three of them suggesting that since Canada respected its environment, it was more likely to respect its citizens. For example, Elena said:

I thought that the coological system in Canada was in better shape. As a result I thought that human relations should be better, because it is all connected

and Oleg said:

There are images of nature on Canadian flag, and on coins. If they take nature seriously, like on money or on the flag, this is a sign of humanity. This reflects its attitudes in general. If there were two sickles, for example, you would look at the country differently.

\section{The Québecois/Montréalals Dream}

America as the North American continent serves as the ideological backdrop: the burden placed upon the claimant once she or he has arrived is to situate her or himself into the specific area of Canada and, eventually, Québec. Unlike the Peruvians interviewed, who consciously chose the Latino culture in Montreal, or potential immigrants who are led (by well-informed lawyers) to invoke their adoration of the French language and of Québec culture in order to be accepted according to the particularities of the Québec system, refugee claimants from this group seldom invoked arguments for their choice of Québec over Ontario (or any other province), or Montréal over Toronto (or any other major city). There were a few exceptions. Tatians said: 
I wanted to go to Montrical, Ottawa, and Calgary. I knew about Calgary from the Olympics, and Ottawa as the capital. I knew about Montrtal from the Olympics, and from my friends.

\section{Lilia said:}

I heard that the Olympics were in Montreal, but I didn't think I would live in Montríal specifically. I didn't care, as long as it was Canade. I thought of Vancouver, since it was warmer.

\section{Mark said:}

French is more difficult for me than English. I think that in the future I will go to another province. I initially imagined that I would live in Canada, not exactly Montrieal. I had not heard too much about Canada. I read books about Canada, about Olympic games in 1976. Not exactly Montríal.

Alexander said: 'I came to Montreal because my image of Canada was from pictures of Vancouver and Toronto and Montréal.' These examples do not demonstrate a firm commitment to either Québec or to Montréal, but they do show the importance of international showcases, such as the Olympics, and sporting events, such as hockey tournaments. Every single claimant mentioned hockey as a factor in their perception of Canada. In this regard, the true Québec diplomatic core is the Montréal Canadians Hockey Team. Leonid said:

I knew about hockey. I had the impression that the country spent a lot of money on sports. I had heard of the hockey teams; Edmonton, Calgary, Toronto, Montrital. I heard of the Edmonton Oilers, so they must extract oil.

Alexander said:

I knew more about Canadian sports than Americans, because of hockey. One of our players played for Vancouver. Montrial Canadians I knew as soon as I started to think.

Valeri said:

I had heard a little about American sports, I knew a little about American football and baseball, and hockey of course. There was a lot of information about hockey. If you wanted to know more about sports you could have found out; in my childhood I knew about skiers, skaters, track and field, and so forth, but then $I$ was not interested.

There is no difference in this regard between the sexes. Tatiana said: We had reports about hockey, and I thought to myself it would be an interesting country'. Lyubov said:

I saw interviews with Canadian hockey players. Tretiak used to invite Russian teams and there were interviews on TV. Everybody watched hockey. I atways associated Canada with hockey.

Ivana knew major cities only because of hockey: 'Vancouver, Edmonton, Calgary, Toronto, Montréal, Winnipeg, Ottawa; all hockey teams!' 
If they did distinguish Québec from Canada on grounds other than sports, it was generally on the basis of language (a fact that is generally learned just prior to their departure from the ex-Soviet Union). When pressed, they often mentioned that Québec was probably a French colony and therefore in some ways similar to France. But this was seldom a factor in the choice of Québec as destination for the claim. In the few cases in which the claimant did distinguish between Québec and Canada, they mentioned their fear of nationalism and the issue of their having to learn two more languages; but not one interviewee thought that French was the dominant language. On a more positive note, some claimants pictured Québec, and especially Montréal, as being a little bit 'crazier', somewhat more similar to regions in the ex-Soviet Union than the rest of Canada, and they thought that there would be a few French customs. The major issue, however, is a pragmatic one: Montréal is closer to New York (where many claimants first landed), it has the reputation of accepting more refugees (two claimants mentioned this as a reason), and it is perceived as being more European (three mentioned this as a motivation).

\section{Conchusion: Parts of a Whole}

The choice of country is often motivated by perceptions and elucidated by complex discursive strategies, neither of which are easy to pin down or quantify. It could be suggested that reference to the American Dream as argumentative structure is a means of illuminating one more element in the complex array of discursive practices present in the Convention refugee hearing, evoked (along with an array of other attempts at self-justification) by Convention refugees to achieve successful admission into Canada following a long flight which has brought them to an (often frigid) place that is far away from home, loved ones and familiar scenes. But there is another side. To the extent that the American Dream is also played up by Americans, this was done to 'prove' the superiority of their culture and the potentially Utopic qualities of American life. The 'Cold War' was, from this perspective (there are others), a long-standing stratagem that existed to prolong and justify certain American and Soviet practices at home and abroad; governments invaded territories, enforced blockades, subsidized supposedly 'capitalist' enterprises with public money, punished regimes that did not uphold the vahues of one side or another, sold arms to obviously dictatorial and oppressive regimes, and engaged in a massive war of words to prove the obvious superiority of their side over the other. The American Dream, particularly for persons from the former Soviet Union, came to represent a promise of a better world, a pledge to fulfil the fantasies of those willing to embrace its ideology. Half of the persons in this group stated that they expected a warm welcome and a minimum of procedural wrangling from Canadian authorities, and were disappointed when authorities did not live up to their 'promise'. This points to another overriding problem, regarding the lack of adequate information for persecuted persons. Persons in difficulty could be made aware of options available to them, and persons who 
think that they have American qualities and therefore should be accepted into Canada can be encouraged to find ways of immigrating that are more appropriate than the refugee claim. Policy-makers must look to the sometimes confused and often contradictory testimony of refugee claimants and see therein the conflicting signals of benevolence and imperialism that are sent through First World practices; and they must look to the choices of claimants and see reflected therein their own objectives and procedures. In this way other human beings' attempts at seeking not only 'freedom from', but also 'freedom to', might begin to look not only familiar, but desirable.

1. This group represents a portion of a larger sampling of refugee claimants from the former Soviet Union, Israel, Pakistan and Peru interviewed to determine the basis of choices made subsequent to a Convention refugee's decision to flee the country of origin. The profile of those interviewed from the former Soviet Union is hereby provided since one of the conclusions of the study is that there is a strong correlation between profile, information available to the claimant and the timing of the decision to leave the country (i.e. the level of persecution that the claimant is willing to tolerate).

Half of the claimants considered themselves Russian Orthodox, with the remainder almost equally split between atheists and Jews. The level of education was high; 28 per cent had graduated from university, 43 per cent from college and 28 per cent from technical school. Half of the claimants spoke some English upon arrival in Canada, and another 21 per cent spoke some other language than Russian. Numerous professions were represented within the sampling, including factory workers (28 per cent), educators (21 per cent), sailors (15 per cent), doctors (15 per cent), entertainment ( 7 per cent), hotelier ( 7 per cent) and without employment (7 per cent). Three-quarters of the claimants claimed that their families owned property in the former Soviet Union. Family life was turbulent; although all of those interviewed had been married, half of them were now divorced. The ethnic origin of the spouse, important in terms of persecution on the basis of religion or nationality, included Jews and half-Jews (39 per cent), Kazakhs ( 7 per cent), Ukrainians ( 7 per cent) and Russians ( 50 per cent). The level of education of the spouses was high; 29 per cent had graduated from university, 64 per cent from institutes and 7 per cent from high school. Unlike other factors studied for this research, the evocation of the American Dream rarely coincides consistently with a particular claimant profile; nonetheless, particular details of individuals mentioned in this article will be mentioned when pertinent.

ABETLA, I and TROPER, H. (1982) None is Too Mann: Canade and the Jews of Europe, 19331948, Toronto, Lester and Orpen Dennys.

ADELMAN, H. (ed.) (1991) Refingee Policy: Canada and the United States, Toronto, York Lanes Press.

BARSKY, R F. (1993) The Interpreter and the Canadinn Convention Refuge Hearing Crossing the Potentially Lifo-threatening Boundaries between 'cocosde-eh', 'chuct-chuct,' and 'cot-cot-cot', Tractuction, Termbrologie, Rédaction: Erudes sto le Texte et ses Tranformations, 6:2, pp. 131-156.

- - (1994a) Construeting a Praductive Other: Discourse Theory and the Canvention Refugee Hearing, Amsterdam/Philadelphin, John Benjomins.

- - (1994b) Why Canada? Why Quebec? Assessing the Canvention Refugee's Choice of Hast Conoutes in 1992, Ottawn, CESAC (Government of Canada) and Montrtal, MAIICC (Government of Quibec). 
- - (1995) The Construction of the Other and the Destruction of the Setf: The Case of the Convention Hearings', in Brinker-Gabler, G., ed., Encosnterting the Other/s, New York, SUNY P. BICKLEY, V. C. (1982) 'Langurge as the Bridge', Pp. 99-125 in S. Bochner, ed, Cultures in Contact, Oxford, Pergemon.

BOLLAG, B. and CRISP, J. (1987) 'Airtines on Collixion Course', Refugees, 43, pp. 17-18.

CHAMBERS, R. (1986) 'Hidden Losers' The Impact of Rural Refuges and Refugee Programs on Poorer Hosts', International Migration Reviow, 20:2, Pp. 245-263.

CHOMSKY, N. (1972) Problems of Krowledge and Freedom, New York, Vintage.

- - (1978) 'Human Rights' and American Foreign Policy, Nottingham, Spakesman Books.

- - (1992) Chronicles of Dissent: Interviews with David Barsonion, Monroe, Maine, Common Courage/Stirling, Scotland, AK Prean.

CDISP, J. (1987) 'United Kingdom: Turbulent Pasafo for Carriers' Bill', Refugees, 43, pp. 15-17. DEN HOND, M. (1988) 'Jet-Age Refurees: In Search of Balance and Cooperation', Pp. 49-56 in Martin, D., ed. The New Asyhen Seekers: Refugee Law in the 1980,, Dordrecht/Boston/London, Martinus Nijhoff.

EBBEL, M. and FLALA, P. (1983) 'Sous le consensus, h xénophobic', MÉmotres et Documents, 16, Lausanne, Institut de Sciences Politiques.

ESSED, P. (1991) Understanding Everyday Ractem, Newbury Park, CA, Sage.

GEERTZ, C. (1983) The Interpretation of Cultures, New Yot, Basic Books.

GILAD, L (1990) The Northem Route: An Exhrography of Refugee Experiences, St. John's, Nild. Institute of Social and Economic Research

GRAHL-MADSEN, A (1987) 'Stemming the Tide', In Defense of the Alien, 10, pp. 213-235.

GUDYKUNST, W. B. and YOUNG, Y. X. (1984) Commanteatting with Strongers, Reading MA, Addison Wealey.

HATHAWAY, J. C. (1990) 'A Reconsideration of the Undertying Premixe of Refugee Lew', Harvard Intemational Low Joumal, 31:1, pp. 129-183.

- - (1991a) The Law of Refugee Stans, Toronto, Butterworths.

- - (1991b) 'Reconceiving Refugec Law as Humen Rights Protection', Joumal of Refugee Studies, 4, pp. 113-31.

- - (1993) Rebullding Trust: Report of the Review of Fundomental Justice in Information Gathering and Dissemination at the Immigration and Refugee Board of Canoda, Ottawa, IRB.

HELLY, D. (1992) L'Immigration powr quol fatre?, Quebec, IQRC.

JAEGER, G. (1988) 'Irregalir Movements. The Concept and Possible Solutions', pp 23-48 in Martin, D. A., ed., The New Asybum Seekers: Refugee Law in the 1980s, Dordrocht/Boston/ London, Martinus Nijhofl.

KÃLN, W. (1986) Troubled Communication: Cross-Cultural Misunderstanctings in the Asylum Hearing, International Migration Review, 20-2, pp. 230-241.

IOOLE, T. and TEN THUJE, J. D. (1994) The Canstruction of intercultural Discourse, Ameterdam, Rodopi.

MEYER, M. (1992) Question de thétorique, Paris, PUF.

VAN DLIK, T. (1987) Commonicating. Raciom: Ethnic Prejudice in Talk and Thought, Newbury Park, CA, Sage.

MS received May 1994; revised MS received January 1995

I would like to thank the Social Sciences and Humanities Research Council, Canadian Heritage, the Ministère des Affaires Internationales, de l'Immigration et des Communautés Culturelles, and the Institut National de la Recherche Scientifique. 